\title{
ANALISIS PERILAKU KONSUMEN TERHADAP NIAT MEMBELI MELALUI SIKAP DAN INTENTION TO ENGAGE PADA MEDIA SOSIAL
}

\author{
Johan Prapta Wijaya \\ Program Studi Manajemen, Fakultas Ekonomi dan Bisnis, Universitas Pelita Harapan, Indonesia \\ johan.prapta@yahoo.co.id \\ Margaretha Pink Berlianto \\ Program Studi Manajemen, Fakultas Ekonomi dan Bisnis, Universitas Pelita Harapan, Indonesia \\ Margaretha.berlianto@uph.edu
}

\begin{abstract}
ABSTRAK
Penelitian ini bertujuan untuk menginvestigasi pengaruh positif dari perceived usefulness, compatibility, enjoyment, kredibilitas, peer communication terhadap sikap, menginvestigasi pengaruh positif sikap terhadap intention to engage, dan mengivestigasi pengaruh positif intention to engage terhadap niat membeli. Penelitian ini menggunakan pendekatan kuantitatif dengan jumlah sampel sebanyak 215 orang yang berdomisili di Jabodetabek. Penelitian ini menggunakan purposive sampling, dengan kriteria individu yang menggunakan media sosial Instagram dan mengikuti salah satu akun Instagram sebuah merek. Metode analisis yang digunakan adalah Partial Least Squares-Structural Equation Modeling (PLS-SEM). Hasil dari penelitian ini menunjukan bahwa perceived usefulness, compatibility, enjoyment, kredibilitas, peer communication berpengaruh positif terhadap sikap, sikap berpengaruh positif terhadap intention to engage dan intention to engage berpengaruh positif terhadap niat membeli. Penelitian ini berhasil memberikan kontribusi bagi pelaku bisnis mengenai faktor-faktor yang memengaruhi sikap pelanggan terhadap media sosial yang digunakan pemasar untuk melakukan kampanye pemasaran dan bagaimana pengaruh sikap tersebut dalam menciptakan customer engagement melalui media sosial yang pada akhirnya mengarah pada niat beli pelanggan.
\end{abstract}

Kata Kunci:

Media Sosial, Sikap, Engagement, Niat Membeli

\begin{abstract}
This study aims to investigate the positive effect of perceived usefulness, compatibility, enjoyment, credibility, peer communication on consumer attitudes, the positive effect of consumer attitudes towards consumers' intention to engage, and the positive effect of consumers intention to engage on consumers' intentions to purchase. This study used a quantitative approach, and the samples of this study were gathered from 215 respondents in the Jabodetabek area. This study uses a non-probability sample design, which is purposive sampling with criteria: an individual who is using social media Instagram and follow at least one retail brand Instagram account. The analysis process used is Partial Least Squares-Structural Equation Modeling (PLSSEM). The results of this study shown that perceived usefulness, compatibility, enjoyment, credibility, peer communication have a positive effect on consumer attitudes, consumer attitudes have a positive effect on consumers' intention to engage, and consumers intention have a positive effect on consumers' intentions to purchase. The study contributes to practitioners regarding influence factors on customer's attitudes toward social media and the effect of customer's attitude on customer engagement toward media social and its impacts on purchase intention.
\end{abstract}

Keywords:

Social Media, Attitude, Engagement, Intention To Purchase 


\section{PENDAHULUAN}

Perkembangan internet dan media sosial telah membuat perubahan dalam aktivitas pemasaran yang dilakukan oleh pelaku bisnis. Berdasarkan data dari APJII (2017), jumlah pengguna internet di Indonesia sebanyak 143,26 juta jiwa $(54,68 \%)$, dengan penggunaan untuk media sosial sebesar $87,13 \%$, dimana 97,5\% untuk berbagi informasi dan $84,6 \%$ untuk berdagang $(84,6 \%)$. Konten komersial yang paling sering dikunjungi pelanggan adalah toko online $(62 \%)$. Berdasarkan fakta diatas, maka pelaku bisnis perlu memanfaatkan media sosial untuk melakukan kampanye pemasaran dimasa yang akan datang. Pemasaran melalui media sosial, memungkinkan pengguna atau pelanggan untuk berhubungan, berinteraksi, memproduksi, dan berbagi isi pesan dengan penjual dan pelanggan lainnya (Lewis, 2009) dan penjual dapat menjalin hubungan dua arah dan membangun customer engagement (Hennig-Thurau et al., 2010; Sashi, 2012).

Akan tetapi, meskipun penjual dapat menarik jutaan konsumen untuk mengikuti dan engage dengan media sosial mereka, hal ini tidak serta-merta berarti bahwa konsumen akan membeli produk mereka. Oleh karena itu, pelaku bisnis harus mengetahui faktor-faktor apa saja yang dapat memengaruhi customer engagement. Menurut Bianchi \& Andrews (2018) agar tercipta customer engagement, pelanggan harus terlebih dahulu memiliki sikap yang positif mengenai penjual tersebut. Terdapat beberapa faktor yang dapat memengaruhi sikap positif pelanggan terhadap penjual, seperti perceived usefulness, compatibility, enjoyment, kredibilitas, dan peer communication. Oleh karena itu, penelitian ini berupaya untuk menggali lebih dalam pengaruh perceived usefulness, compatibility, enjoyment, kredibilitas dan peer communication terhadap sikap pelanggan yang pada akhirnya berpengaruh terhadap intention to engage. Tambahan lainnya, berdasarkan pencarian literatur penelitian sebelumnya, masih sedikit penelitian mengenai faktor yang memengaruhi sikap konsumen terhadap penjual yang melakukan kampanye pemasaran via media sosial Instagram, bagaimana pengaruh sikap konsumen terhadap intention to engage dan pengaruh intention to engage tersebut terhadap niat membeli produk atau layanan melalui media sosial di Indonesia. Untuk itu, penelitian 
ini bertujuan untuk menginvestigasi faktorfaktor yang memengaruhi sikap pelanggan terhadap sebuah merek dalam konteks media sosial Instagram, yaitu menginvestigasi pengaruh perceived usefulness, compatibility, enjoyment, kredibilitas, dan peer communication terhadap sikap, menginvestigasi pengaruh sikap pelanggan terhadap intention to engage dan menginvestigasi pengaruh intention to engage terhadap niat untuk membeli melalui media sosial. Penelitian ini mengadopsi penelitian Bianchi \& Andrews (2018) yang dilakukan dalam pada konteks industri ritel di Chile.

\section{TINJAUAN TEORI DAN
T}

\section{PENGEMBANGAN HIPOTESIS}

\section{Sikap Pelanggan}

Sikap merupakan suatu evaluasi dan hasil dari pembelajaran berulang dan menunjukan bahwa seseorang menyukai atau tidak menyukai suatu objek, isu, orang, ataupun perilaku. Sikap merupakan sesuatu yang dipelajari dan cenderung bertahan dari waktu ke waktu (Hoyer, MacInnis, \& Pieters, 2016.; Lee \& Hsieh, 2009) menyatakan bahwa sikap konsumen mengacu pada kecenderungan untuk merespon dengan cara yang menguntungkan atau tidak, setelah menerima pesan iklan dan menjalani respon emosional serta pemikiran kognitif. Pada penelitian ini menggunakan definisi sikap dari Hoyer et al. (2016).

\section{Perceived usefulness}

Jahangir \& Begum

mendefinisikan perceived usefulness sebagai sejauh mana seseorang percaya bahwa menggunakan sistem tertentu dapat meningkatkan kinerja pekerjaannya. Dalam konteks penggunaan internet, perceived usefulness didefinisikan sebagai persepsi individu ketika menggunakan internet sebagai media belanja akan meningkatkan performa mereka, memberikan banyak alternatif produk, memungkinkan individu dalam memenuhi kebutuhan yang lebih cepat, membuat kegiatan berbelanja menjadi lebih efektif karena lebih banyak produk alternatif, dan mengurangi waktu untuk kegiatan yang tidak produktif (Juniwati, 2014). Menurut Bianchi \& Andrews (2018), semakin baik perceived usefulness akan semakin mendorong penerimaan untuk menggunakan suatu teknik informasi dan perilaku para pengguna. Pernyataan ini 
didukung oleh penelitian sebelumnya (Elkaseh,

Kok, \& Chun, 2016), Kanchanatanee, Suwanno, \& Jarernvongrayab (2014), dan Lee, Tsao, \& Chang (2015). Berdasarkan uraian diatas, maka:

H1: Perceived usefulness berpengaruh positif dengan sikap.

\section{Compatibility}

Compatibility dapat memengaruhi tingkat adopsi seseorang terhadap sebuah inovasi baru (Kanchanatanee et al., 2014). Menurut Kotler \& Armstrong (2016), compatibility adalah sejauh mana inovasi sesuai dengan nilai-nilai dan pengalaman calon pelanggan. Untuk itu, sebuah inovasi yang akan diperkenalkan harus sesuai dan memiliki daya adaptif terhadap kondisi biofisik, sosial, ekonomi dan budaya yang ada. Penelitian terdahulu menemukan bahwa compatibility berpengaruh terhadap sikap pelanggan (Jamshidi \& Kazemi, 2019; Kanchanatanee et al., 2014; Karahoca, Karahoca, \& Aksöz, 2018; Lee, Tsao, \& Chang, 2015; ReyesMercado \& Rajagopal,2017; Wang, Yuen, Wong, \& Teo, 2018). Maka:

H2: Compatibility berpengaruh positif dengan sikap.

\section{Enjoyment}

Enjoyment mewakili motivasi intrinsik seseorang untuk menggunakan sebuah sistem (Bashir \& Madhavaiah, 2015). Enjoyment adalah sejauh mana aktivitas menggunakan sistem tertentu dianggap menyenangkan dalam dirinya sendiri, terlepas dari konsekuensi kinerja yang dihasilkan dari penggunaan sistem (Anton, Camarero, \& Rodriguez, 2013). Penelitian sebelumnya menemukan bahwa enjoyment berpengaruh positif terhadap sikap (Bashir \& Madhavaiah, 2015; Chiang, 2013; Lee et al., 2015). Maka berdasarkan uraian diatas, dibentuklah hipotesis sebagai berikut:

H3: Enjoyment berpengaruh positif dengan sikap.

\section{Kredibilitas}

Kredibilitas adalah sejauh mana penerima melihat sebuah sumber informasi memiliki pengetahuan, keterampilan atau pengalaman yang relevan dan percaya bahwa sumber informasi memberikan informasi yang objektif dan tidak bias. Kredibilitas ditemukan memiliki pengaruh positif terhadap sikap pelanggan (Colton, 2018; Mumuni, Lancendorfer, O’Reilly, \& MacMillan, 2019; Munnukka, Uusitalo, \& Toivonen, 2016; 
Nayeem, Murshed, \& Dwivedi, 2019).

Berdasarkan uraian diatas, maka:

H4: Kredibilitas berpengaruh positif dengan sikap.

\section{Peer communication}

Peer communication diartikan sebagai peluang bagi pengguna untuk terlibat dalam kegiatan komunikasi, mempengaruhi, dan dipengaruhi oleh orang lain (Park, Jun, \& Lee, 2015; Zhang \& Daugherty, 2009). Konsumen dapat terhubung dengan orang lain di situs media sosial dengan berbagi minat dan pandangan yang sama. Peer communication tentang produk di media sosial mempengaruhi keputusan pembelian secara langsung melalui konformitas teman sebaya dan secara tidak langsung dengan memperkuat keterlibatan produk (Muralidharan \& Men, 2015). Niat individu untuk menggunakan media sosial akan meningkat ketika pengguna percaya bahwa berbagi informasi dan terhubung dengan orang lain memungkinkan pengguna tersebut untuk mengenal lebih banyak orang (Kwon \& Wen, 2010). Peer communication ditemukan berpengaruh positif terhadap sikap (De Gregorio \& Sung, 2010; Kwon, Kim, Sung, \& Yoo, 2014; Wang, Yu, \& Wei, 2012).
Berdasarkan uraian diatas, maka:

H5: Peer communication berpengaruh positif dengan sikap.

\section{Intention to engage}

Customer engagement dengan sebuah merek telah menjadi konsep penting dalam penelitian dibidang pemasaran dan ritel (Brodie, Hollebeek, Jurić, \& Ilić, 2011; Graffigna \& Gambetti, 2015), karena dapat membuat konsumen merasakan hubungan yang lebih kuat dengan merek dan perusahaan (Calder, Malthouse, \& Schaedel, 2009; Chang \& Fan, 2017), serta lebih mungkin untuk berpartisipasi dalam komunitas merek (Algesheimer, Dholakia, \& Herrmann, 2005). Bianchi \& Andrews (2018) menyatakan bahwa customer engagement sebagai sebuah manifestasi perilaku yang mengarahkan konsumen untuk terus berkomunikasi dengan merek dan menghasilkan niat pembelian. Ketika konsumen terlibat dengan sebuah merek melalui media sosial, konsumen dapat menambahkan nilai ke merek tersebut dengan menghasilkan konten, menjadi pendukung atau dengan mempengaruhi perilaku pembelian pelanggan lain melalui kata elektronik dari word-of-mouth (Bruhn, Schoenmueller, \& 
Schäfer, 2012; Kozinets, de Valck, Wojnicki,

\& Wilner, 2010). Beberapa penelitian terdahulu menemukan bahwa sikap berpengaruh positif terhadap consumers' intention to engage (Bianchi \& Andrews, 2018; Liu \& Zhao, 2015; Puspitasari \& Chien, 2014), maka:

H6: Sikap berpengaruh positif dengan consumers' intention to engage.

\section{Niat untuk Membeli}

Niat untuk membeli adalah niat seseorang untuk membeli merek tertentu yang telah dipilih untuk diri sendiri setelah mengevaluasinya (Bianchi \& Andrews, 2018).

Konsumen yang terlibat dengan sebuah merek akan membeli membeli produk atau layanan melalui platform media sosial mereka (Yadav, de Valck, Hennig-Thurau, Hoffman, \& Spann, 2013).

Menurut Hollebeek (2011), semakin tinggi niat konsumen untuk terlibat dengan sebuah merek melalui media sosial secara positif berhubungan dengan niat konsumen untuk membeli melalui media sosial. Pernyataan ini didukung oleh penelitian sebelumnya (Altschwager, Conduit, BouzdineChameeva, \& Goodman, 2014; Bianchi \& 142
Andrews, 2018; Blasco-Arcas, HernandezOrtega, \& Jimenez-Martinez, 2016). Maka hipotesis diusulkan:

$\mathrm{H} 7$ : Intention to engage berpengaruh positif dengan niat untuk membeli melalui sosial media

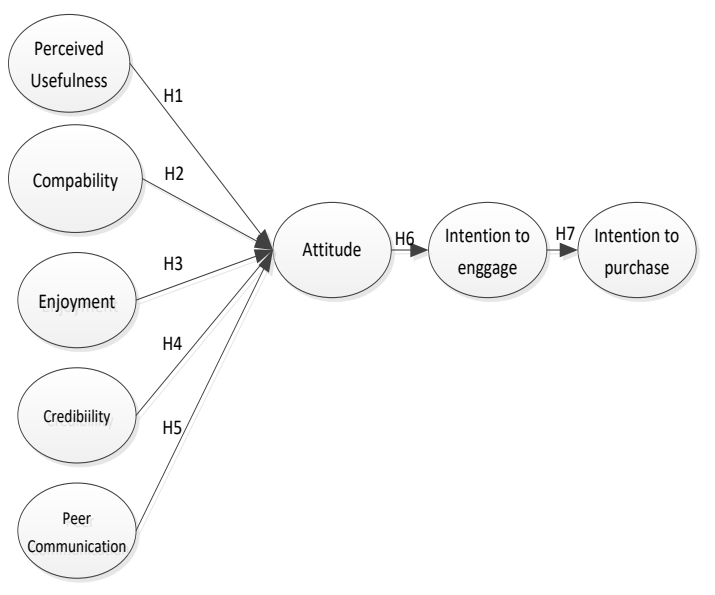

Gambar 1. Kerangka Konseptual

Sumber: Bianchi \& Andrews (2018)

\section{METODE RISET}

Jenis penelitian ini adalah penelitian kuantitatif dengan populasinya adalah individu yang berdomisili di Jabodetabek yang menggunakan sosial media Instagram, dan mengikuti salah satu akun Instagram sebuah merek. Pemilihan sosial media Instagram berdasarkan pertimbangan bahwa Instagram merupakan media sosial yang memiliki pertumbuhannya paling signifikan dan penggunanya paling aktif (Bohang, 2018). Teknik pengambilan sampel menggunakan 
desain sampel non probabilitas yang bersifat purposive sampling, dengan kriteria individu yang berdomisili di Jabodetabek, menggunakan media sosial Instagram dan mengikuti akun Instagram salah satu merek. Jumlah sampel yang digunakan pada penelitian ini adalah sebanyak 234 responden dengan pertimbangan jumlah indikator dikali 6 (Hair, Black, \& Babin, 2013).

Definisi konseptual dan operasional pada penelitian ini adalah sebagai berikut. Perceived usefulness didefinisikan sebagai sejauh mana seseorang percaya bahwa menggunakan sistem tertentu dapat meningkatkan kinerja pekerjaannya (Jahangir \& Begum, 2008), yang terdiri dari tujuh indikator yang diadaptasi dari Bianchi \& Andrews (2018) dan Park (2009). Compatibility adalah sejauh mana inovasi sesuai dengan nilai-nilai dan pengalaman calon pelanggan (Kotler \& Armstrong, 2016), dengan lima indikator yang diadaptasi dari Bianchi \& Andrews (2018) dan Ozturk, Bilgihan, Nusair, \& Okumus, (2016). Enjoyment diartikan sebagai sejauh mana aktivitas menggunakan sistem tertentu dianggap menyenangkan dalam dirinya sendiri, terlepas dari konsekuensi kinerja yang dihasilkan dari penggunaan sistem (Anton et al., 2013), terdiri dari enam indikator yang diadaptasi dari Bianchi \& Andrews (2018) dan Soares \& Pinho (2014). Kredibilitas adalah sejauh mana penerima melihat sumber informasi memiliki pengetahuan, keterampilan atau pengalaman yang relevan dan percaya bahwa sumber informasi memberikan informasi yang objektif dan tidak bias (Belch \& Belch, 2015), dengan empat indikator yang diadaptasi dari Bianchi \& Andrews (2018). Peer communication diartikan sebagai peluang bagi pengguna untuk terlibat dalam kegiatan komunikasi, memengaruhi, dan dipengaruhi oleh orang lain (Park et al., 2015; Zhang \& Daugherty, 2009), dengan empat indikator yang diadaptasi dari Bianchi \& Andrews (2018). Sikap adalah keseluruhan evaluasi yang menunjukan bahwa seseorang menyukai atau tidak menyukai suatu objek, isu, orang, ataupun perilaku (Hoyer et al., 2016), yang terdiri dari lima indikator yang diadaptasi dari Bianchi \& Andrews (2018) dan Park (2009). Intention to engage adalah hubungan keterhubungan dengan merek, di mana konsumen termotivasi untuk berinteraksi dengan merek, menciptakan nilai, dan 
mengembangkan koneksi merek yang kuat (Altschwager et al., 2014), terdiri dari tiga indikator yang diadaptasi dari Bianchi \& Andrews (2018). Niat untuk membeli adalah niat seseorang untuk membeli merek tertentu yang telah dipilih untuk diri sendiri setelah mengevaluasinya (Bianchi \& Andrews, 2018) dengan lima indikator yang diadaptasi dari Bianchi \& Andrew (2018) dan Schlosser, White, \& Lloyd (2006).

Pengujian validitas dan reliabilitas dilakukan dengan menguji validitas konvergen dengan persyaratan yaitu nilai loading factor harus melebihi dari 0,6, nilai average variance extracted (AVE) harus lebih besar dari 0,5, validitas diskriminan yang baik ditunjukkan dari akar kuadrat AVE untuk setiap konstruk lebih besar dari kolerasi antar konstruk dalam model dan nilai composite reliability harus lebih besar dari 0,7 (Ghozali \& Latan, 2015). Metode analisis data menggunakan PLS-SEM dengan persyarata bahwa apabila nilai $\mathrm{t}$ statistik > 1,65 maka hipotesis tersebut dapat diterima.

Pretest dilakukan sebelum dilakukan penyebaran data aktual, dengan jumlah sampel sebanyak 58 responden. Hasil uji validitas dan reliabilitas pada studi pendahuluan telah memenuhi syarat, sehingga dapat dikatakan semua indikator valid dan dapat digunakan pada studi aktual.

HASIL PENELITIAN DAN PEMBAHASAN

Dari 234 kuesioner yang disebarkan, terdapat 215 kuesioner yang layak untuk digunakan dengan tingkat respon sebesar $90 \%$. Profil responden pada penelitian ini adalah sebagai berikut. Pria sebanyak 95 orang $(44,2 \%)$ dan wanita sebanyak 120 orang (55,8\%), dengan usia 17-22 tahun sebanyak $205(95,3 \%)$ dan 23-28 tahun sebanyak 4,6\%. Responden yang berdomisili di Jakarta sebanyak 79 orang $(36,7 \%)$, Tangerang 129 (60\%) dan lainnya 7 (3,3\%). Lama waktu menggunakan Instagram dalam sehari kurang dari 1 jam sebanyak 28 orang (13\%), 1-3jam (90\%), 4-6 jam 68 orang $(31,6 \%)$ dan diatas 7 jam sebanyak 29 orang (13,5\%).

Pada pengujian studi aktual, terdapat beberapa indikator yang dihapus yaitu EJ1, EJ2, dan PC1 karena memiliki nilai outer loading dibawah 0,6 dan nilai AVE dibawah 0.5. Setelah dilakukan penghapusan dan 
pengujian kembali, hasilnya dapat dilihat pada

Tabel 1 dibawah ini.

Tabel 1. Hasil Uji Validitas Konvergen

\begin{tabular}{|c|c|c|c|}
\hline Variable & Indikator & $\begin{array}{l}\text { Outer } \\
\text { Loading }\end{array}$ & Hasil \\
\hline \multirow{7}{*}{$\begin{array}{l}\text { Perceived } \\
\text { usefulness }\end{array}$} & PU 1 & 0,757 & Valid \\
\hline & PU 2 & 0,752 & Valid \\
\hline & PU 3 & 0,808 & Valid \\
\hline & PU 4 & 0,772 & Valid \\
\hline & PU 5 & 0,820 & Valid \\
\hline & PU 6 & 0,739 & Valid \\
\hline & PU 7 & 0,723 & Valid \\
\hline \multirow[t]{5}{*}{ Compatibility } & $\mathrm{CO} 1$ & 0,813 & Valid \\
\hline & $\mathrm{CO} 2$ & 0,808 & Valid \\
\hline & $\mathrm{CO} 3$ & 0,796 & Valid \\
\hline & $\mathrm{CO} 4$ & 0,837 & Valid \\
\hline & $\mathrm{CO} 5$ & 0,697 & Valid \\
\hline \multirow[t]{4}{*}{ Enjoyment } & EJ3 & 0,673 & Valid \\
\hline & EJ4 & 0,825 & Valid \\
\hline & EJ5 & 0,845 & Valid \\
\hline & EJ6 & 0,815 & Valid \\
\hline \multirow[t]{4}{*}{ Kredibilitas } & CR1 & 0,768 & Valid \\
\hline & CR2 & 0,856 & Valid \\
\hline & CR3 & 0,837 & Valid \\
\hline & CR4 & 0,796 & Valid \\
\hline Peer & PC2 & 0,867 & Valid \\
\hline \multirow[t]{2}{*}{ communication } & PC3 & 0,891 & Valid \\
\hline & PC4 & 0,890 & Valid \\
\hline \multirow[t]{5}{*}{ Sikap } & AT1 & 0,826 & Valid \\
\hline & AT2 & 0,827 & Valid \\
\hline & AT3 & 0,812 & Valid \\
\hline & AT4 & 0,790 & Valid \\
\hline & AT5 & 0,799 & Valid \\
\hline Intention to & IE1 & 0,900 & Valid \\
\hline \multirow[t]{2}{*}{ engage } & IE2 & 0,916 & Valid \\
\hline & IE3 & 0,820 & Valid \\
\hline \multirow{5}{*}{ Niat membeli } & IP1 & 0,786 & Valid \\
\hline & IP2 & 0,827 & Valid \\
\hline & IP3 & 0,834 & Valid \\
\hline & IP4 & 0,787 & Valid \\
\hline & IP5 & 0,736 & Valid \\
\hline
\end{tabular}

Sumber : Hasil Smart PLS (2019)

Pada Tabel 2, Nilai AVE variabel diatas

0,5 sehingga memenuhi persyaratan. Nilai

Composite Reliabilty memenuhi persyaratan

karena lebih dari 0,7 (Ghozali dan Latan,

2014).
Tabel 2. Hasil Uji Average Variance Extracted (AVE)

\begin{tabular}{lcll}
\hline Variabel & AVE & CR & \\
\hline PU & 0,590 & 0,909 & \\
Compatibility & 0,627 & 0,893 & \\
Enjoyment & 0,628 & 0,870 & \\
Kredibilitas & 0,664 & 0,888 & \\
PR & 0,779 & 0,914 & \\
Sikap & 0,658 & 0,906 & \\
IE & 0,774 & 0,911 & \\
IP & 0,632 & 0,895 & \\
\hline PU=Perceived & usefulness, & $P R=$ & Peer
\end{tabular}
communication, $I E=$ Intention to engage, $I P=\mathrm{Niat}$ Membeli $A V E=$ Average Variance Extracted, $C R=$ Composite Reliability

Sumber : Hasil Smart PLS (2019)

Berdasarkan hasil dari Tabel 3 dapat disimpulkan bahwa penelitian ini memiliki validitas diskriminan yang baik, karena seluruh variabel yang ada memiliki nilai akar kuadrat AVE lebih besar dari kolerasi antar konstruk.

Tabel 3. Hasil Uji Validitas Diskriminan

\begin{tabular}{|c|c|c|c|c|c|c|c|c|}
\hline & AT & $\mathrm{CO}$ & CR & EJ & IE & $\mathrm{PC}$ & $\mathrm{PU}$ & IP \\
\hline $\mathrm{AT}$ & 0,811 & & & & & & & \\
\hline $\mathrm{CO}$ & 0,561 & $\mathbf{0 , 7 9 2}$ & & & & & & \\
\hline $\mathrm{CR}$ & 0,487 & 0,393 & 0,815 & & & & & \\
\hline EJ & 0,555 & 0,465 & 0,357 & $\mathbf{0 , 7 9 3}$ & & & & \\
\hline IE & 0,623 & 0,480 & 0,431 & 0,516 & $\mathbf{0 , 8 8 0}$ & & & \\
\hline PC & 0,523 & 0,487 & 0,441 & 0,472 & 0,460 & $\mathbf{0 , 8 8 3}$ & & \\
\hline PU & 0,462 & 0,460 & 0,322 & 0,413 & 0,506 & 0,435 & 0,768 & \\
\hline IP & 0,482 & 0,496 & 0,242 & 0,379 & 0,431 & 0,425 & 0,415 & 0,795 \\
\hline \multicolumn{9}{|c|}{$\begin{array}{l}\text { Note: PU (Perceived usefulness), CO (Compatibility), EJ } \\
\text { (Enjoyment), CR (Kredibilitas), PC (Peer communication), } \\
\text { AT(Sikap), IE (Intention to engage), IP (Niat Membeli) }\end{array}$} \\
\hline
\end{tabular}

Nilai $r$-squares sikap sebesar $0,492 . \mathrm{Hal}$ ini menunjukkan bahwa perceived usefulness, compability, enjoyment, kredibilitas, dan peer communication memengaruhi sikap sebesar 49,2\% sisanya sebesar 50,8\% dipengaruhi oleh faktor lain diluar penelitian ini. Nilai $r$-squares 
intention to engage sebesar 0,385 . Hal ini menunjukkan bahwa pengaruh sikap terhadap intention to engage adalah sebesar 38,5\%, sisanya $61,5 \%$ dipengaruhi oleh faktor lain. Dan nilai $r$-squares pada niat membeli sebesar 0,182. Hal ini menunjukkan bahwa intention to engage memengaruhi niat membeli sebesar $18,2 \%$, sisanya sebesar $81,8 \%$ dipengaruhi oleh faktor lain.

\section{Tabel 4. Hasil Uji Hipotesis}

\begin{tabular}{lll}
\hline Hipotesis & t-stat & Hasil \\
\hline H1: PU $\rightarrow$ sikap & 2,031 & didukung \\
H2: Compatibility $\rightarrow$ sikap & 3,422 & didukung \\
H3: Enjoyment $\rightarrow$ sikap & 3,849 & didukung \\
H4: Kredibilitas $\rightarrow$ sikap & 3,462 & didukung \\
H5: PC $\rightarrow$ sikap & 2,304 & didukung \\
H6: Sikap $\rightarrow$ IE & 14,095 & didukung \\
H7: IE $\rightarrow$ IP & 5,665 & didukung \\
\hline \multicolumn{2}{c}{ Sumber : Hasil Smart PLS (2019) }
\end{tabular}

Hasil pengujian hipotesis pada Tabel 4 menunjukkan bahwa seluruh hipotesis diterima karena memiliki nilai t-statistik > 1,65 (satu arah).

Penelitian ini berhasil menjawab pertanyaan penelitian. Hasil H1 menemukan bahwa perceived usefulnes berpengaruh positif terhadap sikap, yang berarti bahwa semakin baik penilaian konsumen mengenai kegunaan suatu sistem maka semakin baik sikap pelanggan terhadap sistem tersebut. Pada penelitian ini konsumen menganggap Instagram sebuah merek membantu mereka 146 dalam menyelesaikan aktivitas belanja, meningkatkan produktifitas, efektif untuk melakukan pembelian, dan mempercepat transaksi belanja mereka. Hasil penelitian ini mendukung hasil penelitian sebelumnya (Elkaseh et al., 2016; Kanchanatanee et al., 2014; Lee et al., 2015).

Hasil H2 menemukan bahwa compatibility berpengaruh positif terhadap sikap pelanggan. Hal ini berarti bahwa semakin sesuai suatu sistem dengan nilai-nilai yang ada maka akan semakin baik pula sikap pelanggan terhadap sistem tersebut. Hasil ini menunjukkan bahwa mengikuti akun Instagram merek tertentu adalah sesuai dengan kehidupan pelanggan, sesuai dengan kebutuhan dan sesuai dengan gaya hidup mereka. Hasil penelitian ini mendukung hasil penelitian sebelumnya (Jamshidi \& Kazemi, 2019; Karahoca et al., 2018; Lee et al., 2015; ReyesMercado \& Rajagopal, 2017; Xueqin Wang et al., 2018).

\section{Hasil H3 menunjukkan bahwa} enjoyment berpengaruh positif terhadap sikap pelanggan. Hal ini berarti bahwa semakin tinggi tingkat kesenangan terhadap akun Instagram sebuah merek, maka semakin baik 
sikap pelanggan terhadap akun tersebut. Hasil

penelitian ini didukung oleh penelitian

sebelumnya (Bashir \& Madhavaiah, 2015;

Chiang, 2013; Lee et al., 2015). Enjoyment

merupakan faktor yang paling berpengaruh

terhadap sikap pelanggan dibandingkan dengan

faktor lainnya.

Hasil H4 menunjukkan bahwa kredibilitas berpengaruh positif terhadap sikap. Hal ini berarti bahwa semakin baik kredibilitas sebuah akun Instagram pemasar, maka semakin positif sikap pelanggan terhadap akun tersebut. Ketika akun Instagram memiliki kredibilitas yang baik, seperti memenuhi janjinya, memberikan informasi yang jujur tanpa dibuat-buat dan berperilaku etis, maka sikap pelanggan terhadap kampanye pemasaran yang dilakukan via Instagram tersebut menjadi baik. Hasil ini mendukung penelitian sebelumnya (Colton, 2018; Mumuni et al., 2019; Munnukka et al., 2016; Nayeem et al., 2019).

Hasil H5 menemukan bahwa peer communication berpengaruh positif terhadap sikap. Hasil ini menunjukkan bahwa semakin baik komunikasi yang dilakukan oleh teman atau kenalan dalam mengajak orang lain mengikuti akun Instagram merek, maka akan memengaruhi sikap pelanggan terhadap pemasar. Hasil ini mendukung penelitian sebelumnya (De Gregorio \& Sung, 2010; Kwon, Kim, Sung, \& Yoo, 2014; Wang, Yu, \& Wei, 2012).

Hasil H6 menemukan bahwa sikap berpengaruh positif terhadap customers' intention to engage dengan sebuah merek melalui media sosial. Hasil ini menunjukkan bahwa evaluasi positif pelanggan bahwa dengan mengikuti akun Instagram sebuah merek merupakan hal yang baik, positif dan menarik, maka akan memengaruhi niat mereka untuk terlibat dengan akun media sosial pemasar. Hasil ini mendukung penelitian sebelumnya (Bianchi \& Andrews, 2018; Liu \& Zhao, 2015; Puspitasari \& Chien, 2014).

Hasil H7 menunjukkan bahwa intention to engage berpengaruh positif dengan niat membeli melalui media sosial. Hal ini berarti bahwa ketika pelanggan berniat untuk berhubungan dengan akun Instagram pemasar, maka semakin tinggi niat mereka untuk melakukan pembelian melalui akun media sosial merek tersebut. Hasil ini mendukung penelitian sebelumnya (Altschwager et al., 
2014; Blasco-Arcas et al., 2016).

\section{KESIMPULAN DAN SARAN}

Kesimpulan penelitian ini adalah (1) perceived usefulness berpengaruh positif dengan sikap, (2) compatibility berpengaruh positif dengan sikap, (3) enjoyment berpengaruh positif dengan sikap, (4) kredibilitas berpengaruh positif dengan sikap, (5) peer communication berpengaruh positif dengan sikap, (6) sikap berpengaruh positif dengan intention to engage, (7) intention to engage berpengaruh positif dengan niat membeli melalui media sosial.

Implikasi teoritis pada penelitian ini adalah penelitian ini berhasil memberikan tambahan literatur mengenai pengaruh perceived usefulness, compatibility, enjoyment, kredibilitas, dan peer communication, terhadap sikap, pengaruh sikap terhadap intention to engage, dan pengaruh intention to engage terhadap niat membeli, khususnya dalam konteks media sosial yang dapat digunakan untuk penelitian-penelitian selanjutnya.

Implikasi manajerial dari penelitian ini adalah sebagai berikut. Perceived usefulness, compatibility, enjoyment, kredibilitas dan peer communication merupakan faktor-faktor yang berpengaruh positif terhadap sikap pealnggan. Untuk itu, pelaku bisnis yang berkampanye di media sosial harus memperhatikan dan meningkatkan faktor-faktor tersebut. Untuk meningkatkan perceived usefulness dari akun Instagram-nya, pelaku bisnis dapat melakukan hal-hal berikut ini yaitu dengan merespon tanggapan pelanggan dengan cepat, menyediakan katalog atau gambar produk yang memiliki informasi detail yang lengkap dan memberikan proses transaksi yang cepat. Untuk meningkatkan faktor compatibility dari akun Instagram- nya, pemasar dapat melakukannya hal berikut seperti membuat konten kampanye pemasaran yang sesuai dengan gaya hidup dan kebutuhan dari target pasarnya agar pelanggan merasa bahwa akun Instagram pemasar sesuai atau cocok dengan kebutuhan dan gaya hidup pelanggannya. Enjoyment merupakan faktor yang memiliki pengaruh terbesar terhadap sikap pelanggan dibandingkan dengan keempat faktor lainnya. Untuk itu, pemasar harus lebih memperhatikan faktor ini. Untuk meningkatkan enjoyment, pemasar harus memperhatikan dan selektif memilih konten yang di-posting atau 
menyelenggarakan events di media sosial yang dapat menarik minat konsumen untuk dengan melihat, membaca, berkomentar, berinteraksi dan aktivitas lainnya yang dapat menciptakan kesenangan pelanggan dalam berinteraksi dengan pemasar. Selanjutnya untuk meningkatkan kredibilitas, pemasar harus memenuhi brand promise-nya, memberikan informasi yang akurat, mengunggah testimoni pelanggan, tidak memberikan klaim palsu dan berperilaku etis. Pemasar harus meningkatkan peer communication, dengan cara melakukan promosi melalui endorsement, memberikan give away ataupun diskon kepada pelanggan yang melakukan referral, menyebutkan, atau menandai akun Instagram pemasar. Selanjutnya, pemasar juga perlu meningkatkan sikap pelanggan terhadap akun Instagram pemasar agar tercipta intention to engage dengan akun Instagram pemasar tersebut, dengan cara menjaga dan meningkatkan citra positif merek dan kualitas produknya, memberikan pelayanan yang baik sebelum, pada saat dan paska penjualan. Terakhir, pemasar harus meningkatkan customers' engagement dengan cara menggunakan katakata call to action yang menarik perhatian seperti "like dan tag sahabatmu", memberikan give away, menjual barang tertentu dengan sistem lelang, melakukan kuis-kuis pertanyaan dengan fiture polling di akun Instagramnya sehingga dapat meningkatkan engagement konsumen. Dengan adanya keterlibatan ini kiranya dapat menimbulkan niat membeli pelanggan.

Keterbatasan dari penelitian ini adalah penelitian ini tidak mengunakan teknik pengambilan sampel probability sampling sehingga hasinya tidak dapat digeneralisasikan. Kedua merek yang digunakan pada penelitian ini bersifat umum - tidak terbatas hanya satu merek saja.

Saran untuk penelitian selanjutnya adalah Pertama, pada penelitian selanjutnya dapat menambahkan variabel-variabel lain seperti perceived easy of use, keunggulan relatif, observability, trialability, product involvement, visibility, image, kepercayaan, interactivity, perceived informativeness, perceived entertaiment, emotion-based evaluation, dan brand experience yang dapat memengaruhi sikap. Kedua, pada penelitian selanjutnya dapat menginvestigasi pengaruh brand awareness, pleasure, arousal, atau 
dominance terhadap intention to engage.

Ketiga, menginvestigasi pengaruh variabel lain seperti kepercayaan, loyalitas, kepuasan kepuasan atau WOM terhadap niat untuk membeli. Keempat, menginvestigasi pengaruh langung sikap terhadap niat membeli. Kelima, dapat menggunakan sampel dengan jumlah yang lebih besar dan spesifik pada merek tertentu. Keenam, menggunakan media lain seperti Youtube, Twitter atau Facebook Ads. Ketujuh, dalam penelitian selanjutnya dapat melakukan penelitian di wilayah lain yang lebih luas. Kedelapan, menggunakan teknik pengambilan probability sampling agar hasil penelitian ini dapat digeneralisasikan. 


\section{DAFTAR PUSTAKA}

Algesheimer, R., Dholakia, U. M., \& Herrmann, A. (2005). The Social Influence of Brand Community: Evidence from European Car Clubs. The Journal of Marketing, 69(July), 19-34. https://doi.org/10.1016/S0022-3476(86)80122-6

Altschwager, T., Conduit, J., Bouzdine-Chameeva, T., \& Goodman, S. (2014). Customer Engagement: A comparison between Australian and French Wine Events. Academy of Wine Business Research, 1(4), 1-17.

Anton, C., Camarero, C., \& Rodriguez, J. (2013). Usefulness, Enjoyment, and Self-Image Congruence: The Adoption of e-Book Readers. Psychology and Marketing. Psychology and Marketing, 30(4), 372-384.

APJII. (2017). Penetrasi \& Perilaku Pengguna Internet Indonesia 2017. Asosiasi Penyelenggara Jasa Internet Indonesia.

Bashir, I., \& Madhavaiah, C. (2015). Consumer attitude and behavioural intention towards Internet banking adoption in India. Journal of Indian Business Research, 7(1), 67-102. https://doi.org/10.1108/JIBR-02-2014-0013

Belch, G. E., \& Belch, M. A. (2015). Advertising and Promotion: An Integrated Marketing Communications Perspective (10th ed.). UK: McGraw- Hill Education.

Bianchi, C., \& Andrews, L. (2018). Consumer engagement with retail firms through social media: an empirical study in Chile. International Journal of Retail and Distribution Management, 46(4), 364-385. https://doi.org/10.1108/IJRDM-02-2017-0035

Blasco-Arcas, L., Hernandez-Ortega, B. I., \& Jimenez-Martinez, J. (2016). Engagement platforms: The role of emotions in fostering customer engagement and brand image in interactive media. Journal of Service Theory and Practice, 26(5), 559-589. https://doi.org/10.1108/JSTP-12-20140286

Bohang, F. K. (2018). Juni 2018, Pengguna Aktif Instagram Tembus 1 Miliar. Retrieved February 22, 2018, from https://tekno.kompas.com/read/2018/06/21/10280037/juni-2018-pengguna-aktifInstagram-tembus-1-miliar

Brodie, R. J., Hollebeek, L. D., Jurić, B., \& Ilić, A. (2011). Customer engagement: Conceptual domain, fundamental propositions, and implications for research. Journal of Service Research, 1-20. https://doi.org/10.1177/1094670511411703

Bruhn, M., Schoenmueller, V., \& Schäfer, D. B. (2012). Are social media replacing traditional media in terms of brand equity creation? Management Research Review, 35(9), 770-790. https://doi.org/10.1108/01409171211255948

Calder, B. J., Malthouse, E. C., \& Schaedel, U. (2009). An Experimental Study of the Relationship between Online Engagement and Advertising Effectiveness. Journal of Interactive Marketing, 23(4), 321-331. https://doi.org/10.1016/j.intmar.2009.07.002

Chang, S.-W., \& Fan, S.-H. (2017). Cultivating the brand-customer relationship in Facebook fan pages: A study of fast- fashion industry. International Journal of Retail \& Distribution Management, 45(3), 253-270.

Chiang, H. Sen. (2013). Continuous usage of social networking sites: The effect of innovation and gratification attributes. Online Information Review, 37(6), 851-871. https://doi.org/10.1108/OIR-08-2012-0133 
Colton, D. A. (2018). Antecedents of consumer attitudes' toward corporate blogs. Journal of Research in Interactive Marketing, 12(1), 94-104. https://doi.org/10.1108/JRIM-08-2017-0075

De Gregorio, F., \& Sung, Y. (2010). Understanding attitudes toward and behaviors in response to product placement. Journal of Advertising, 39(1), 83-96. https://doi.org/10.2753/JOA00913367390106

Elkaseh, A. M., Kok, W. W., \& Chun, C. F. (2016). Perceived Ease of Use and Perceived usefulness of Social Media for e-Learning in Libyan Higher Education: A Structural Equation Modeling Analysis. International Journal of Information and Education Technology, 6(3), 192-199. https://doi.org/10.7763/ijiet.2016.v6.683

Ghozali, I., \& Latan, H. (2015). Partial Least Squares: Konsep, Teknik dan Aplikasi Menggunakan Program SmartPLS 3.0. Semarang: Universitas Diponegoro.

Graffigna, G., \& Gambetti, R. C. (2015). Grounding consumer-brand engagement: A field-driven conceptualisation. International Journal of Market Research, 57(4), 605-630. https://doi.org/10.2501/IJMR-2015-049

Hair, J. F., Black, W. C., \& Babin, B. J. (2013). Multivariate Data Analysis: A global perspective. (7th ed.). United Kingdom: Pearson Education.

Hennig-Thurau, T., Malthouse, E. C., Friege, C., Gensler, S., Lobschat, L., Rangaswamy, A., \& Skiera, B. (2010). The impact of new media on customer relationships. Journal of Service Research, 13(3), 311-330. https://doi.org/10.1177/1094670510375460

Hollebeek, L. (2011). Exploring customer brand engagement: definition and themes. Journal of Strategic Marketing, 19(7), 555-573. Retrieved from https://www.tandfonline.com/doi/abs/10.1080/0965254X.2011.599493

Hoyer, W. D., MacInnis, D. J., \& Pieters, R. (2016). Consumer Behavior (7th ed.). Boston: Cengage Learning.

Jahangir, N., \& Begum, N. (2008). The role of perceived usefulness, perceived ease of use, security and privacy, and customer attitude to engender customer adaptation in the context of electronic banking. African Journal of Business Management, 2(1), 032-040.

Jamshidi, D., \& Kazemi, F. (2019). Innovation diffusion theory and customers' behavioral intention for Islamic credit card: Implications for awareness and satisfaction. Journal of Islamic Marketing, (2013). https://doi.org/10.1108/JIMA-02-2018-0039

Juniwati. (2014). Influence of perceived usefulness, ease of use, risk on attitude and intention to shop online. European Journal of Business and Management, 6(17), 218-229.

Kanchanatanee, K., Suwanno, N., \& Jarernvongrayab, A. (2014). Effects of Attitude toward Using, Perceived usefulness, Perceived Ease of Use and Perceived Compatibility on Intention to Use EMarketing. Journal of Management Research, 6(3), 1. https://doi.org/10.5296/jmr.v6i3.5573

Karahoca, A., Karahoca, D., \& Aksöz, M. (2018). Examining intention to adopt to internet of things in healthcare technology products. Kybernetes, 47(4), 742-770. https://doi.org/10.1108/K-022017-0045

Kotler, P., \& Armstrong, G. (2016). Principles of Marketing (16th ed.). London: Pearson Education Limited. 
Kozinets, R. V., de Valck, K., Wojnicki, A. C., \& Wilner, S. J. . (2010). Networked Narratives: Understanding Word-of-Mouth Marketing in Online Communities. Journal of Marketing, 74(March), 71-89. https://doi.org/10.1509/jmkg.74.2.71

Kwon, E. S., Kim, E., Sung, Y., \& Yoo, C. Y. (2014). Brand followers: Consumer motivation and attitude towards brand communications on Twitter. International Journal of Advertising, 33(4), 657-680. https://doi.org/10.2501/IJA-33-4-657-680

Kwon, O., \& Wen, Y. (2010). An empirical study of the factors affecting social network service use. Computers in Human Behavior, 26(2), 254-263. https://doi.org/10.1016/j.chb.2009.04.011

Lee, C.-Y., Tsao, C.-H., \& Chang, W.-C. (2015). The relationship between attitude toward using and customer satisfaction with mobile application services An empirical study from the life insurance industry. Journal of Enterprise Information Management, 28(5), 680-697. https://doi.org/10.1108/EL-01-2014-0022

Lee, C. C., \& Hsieh, M. C. (2009). The influence of mobile self-efficacy on attitude towards mobile advertising. In 2009 International Conference on New Trends in Information and Service Science (pp. 1231-1236). https://doi.org/10.1109/NISS.2009.91

Lee, C. Y., Tsao, C. H., \& Chang, W. C. (2015). The relationship between attitude toward using and customer satisfaction with mobile application services: An empirical study from the life insurance industry. Journal of Enterprise Information Management, 28(5), 680-697. https://doi.org/10.1108/JEIM-07-2014-0077

Lewis, B. K. (2009). Social Media and Strategic Communication: Attitudes adn Perceptions Among Collage Students. Oklahoma State University Stillwater. https://doi.org/10.1017/CBO9781107415324.004

Liu, Y., \& Zhao, Y. (2015). Compound Attitudes, Customer Engagement and eWOM: An Empirical Study on WeChat. In International Conference on Information Resources Management (CONFIRM) (pp. 1-18).

Mumuni, A. G., Lancendorfer, K. M., O’Reilly, K. A., \& MacMillan, A. (2019). Antecedents of consumers' reliance on online product reviews. Journal of Research in Interactive Marketing, 13(1), 26-46. https://doi.org/10.1108/JRIM-11-2017-0096

Munnukka, J., Uusitalo, O., \& Toivonen, H. (2016). Credibility of a peer endorser and advertising effectiveness. Journal of Consumer Marketing, 33(3), 182-192. https://doi.org/10.1108/JCM11-2014-1221

Muralidharan, S., \& Men, L. R. (2015). How peer communication and engagement motivations influence social media shopping behavior: Evidence from China and the United States. Cyberpsychology, Behavior, and Social Networking, 18(10), 595-601.

Nayeem, T., Murshed, F., \& Dwivedi, A. (2019). Brand experience and brand attitude: examining a credibility-based mechanism. Marketing Intelligence and Planning, 37(7), 821-836. https://doi.org/10.1108/MIP-11-2018-0544

Ozturk, A. B., Bilgihan, A., Nusair, K., \& Okumus, F. (2016). What keeps the mobile hotel booking users loyal? Investigating the roles of self-efficacy, compatibility, perceived ease of use, and perceived convenience. International Journal of Information Management, 36(6/B), 1350-1359. https://doi.org/10.1016/j.ijinfomgt.2016.04.005

Park, C., Jun, J., \& Lee, T. (2015). Consumer characteristics and the use of social networking sites: A comparison between Korea and the US. International Marketing Review, 32(3-4), 414-437. https://doi.org/10.1108/IMR-09-2013-0213 
Park, S. Y. (2009). An Analysis of the Technology Acceptance Model in Understanding University Students ' Behavioral Intention to Use e-Learning. Educational Technology \& Society, 12(3), $150-162$.

Puspitasari, A. F., \& Chien, W. S. (2014). Brand Awareness, Ad Attıtudes and Ad Features Toward Engagement on Youtube: an Empirical Study of Green Automobiles. Asia Pacific Management and Business Application, 2(3), 170-183. https://doi.org/10.21776/ub.apmba.2014.002.03.3

Reyes-Mercado, P., \& Rajagopal, R. (2017). Adoption of renewable energy technologies in Mexico: The role of cognitive factors and innovation attributes. International Journal of Energy Sector Management, 11(4), 626-649. https://doi.org/10.1108/IJESM-02-2017-0001

Sashi, C. M. (2012). Customer engagement, buyer-seller relationships, and social media. Management Decision, 50(2), 253-272. https://doi.org/10.1108/00251741211203551

Schlosser, A. E., White, T. B., \& Lloyd, S. M. (2006). Converting web site visitors into buyers: How web site investment increases consumer trusting beliefs and online purchase intentions. Journal of Marketing, 70(2), 133-148. https://doi.org/10.1509/jmkg.70.2.133

Soares, A. M., \& Pinho, J. C. (2014). Advertising in online social networks: the role of perceived enjoyment and social influence. Journal of Research in Interactive Marketing, 8(3), 245-263. https://doi.org/10.1108/JRIM-08-2014-001

Wang, X., Yu, C., \& Wei, Y. (2012). Social Media Peer communication and Impacts on Purchase Intentions: A Consumer Socialization Framework. Journal of Interactive Marketing. Journal of Interactive Marketing, 26, 198-208.

Wang, Xueqin, Yuen, K. F., Wong, Y. D., \& Teo, C. C. (2018). An innovation diffusion perspective of e-consumers' initial adoption of self-collection service via automated parcel station. International Journal of Logistics Management, 29(1), 237-260. https://doi.org/10.1108/IJLM12-2016-0302

Yadav, M. S., de Valck, K., Hennig-Thurau, T., Hoffman, D. L., \& Spann, M. (2013). Social commerce: A contingency framework for assessing marketing potential. Journal of Interactive Marketing, 27(4), 311-323. https://doi.org/10.1016/j.intmar.2013.09.001

Zhang, J., \& Daugherty, T. (2009). Third-Person Effect and Social Networking: Implications for Online Marketing and Word-of-Mouth Communication. American Journal of Business, 24(2), 53-64. https://doi.org/10.1108/19355181200900011 